\title{
FAKTOR - FAKTOR PENGAMBILAN KEPUTUSAN PERSETUJUAN PEMBERIAN \\ FASILITAS PEMBIAYAAN KREDIT KENDARAAN BERMOTOR DI PT BCA FINANCE PADA KONSUMEN DAERAH KARAKTER KHUSUS
}

\section{WIENDYA AYU LESTARI}

\author{
windyndoty@gmail.com \\ Mahasiswa Fakultas Ekonomi dan Bisnis Universitas Narotama
}

\begin{abstract}
ABSTRAK
Pinjaman non revolving yang diberikan oleh Bank kepada debitur dengan jumlah ,jangka waktu, dan kondisi tertentu kepada debitur yang memenuhi persyaratan. Pemberian kredit biasanya berjangka waktu relatif sangat pendek, yaitu antara satu sampai 6 tahun. Prinsip pemberian kredit sendiri terkenal dengan konsep 5C yaitu Character (karakter), Capacity (kemampuan mengembalikan utang), Collateral (jaminan), Capital (modal), dan Condition (situasi dan kondisi). Bagi orang bank, nasabah yang memenuhi kriteria $5 \mathrm{C}$ adalah orang yang sempurna untuk mendapatkan pembiayaan. Bank melihat orang yang mempunyai karakter kuat, kemampuan mengembalikan uang, jaminan yang berharga, modal yang kuat, dan kondisi perekonomian yang aman bagaikan melihat sebuah mutiara. Orang seperti ini adalah nasabah potensial untuk diajak bekerjasama atau orang yang layak mendapatkan penyaluran kredit. Pendeknya orang yang mempunyai $5 \mathrm{C}$ yang baik adalah manusia yang ideal, menurut kriteria orang bank. Untuk itulah diperlukan analisis pengenalan calon debitur supaya prinsip kehatihatian tetap dilakukan. Tujuan studi ini adalah untuk mengetahui karakteristik konsumen serta peran kami pihak sebagai pemberi kredit dalam mengambil keputusan apakah konsumen di daerah karakter khusus tersebut dapat dikatakan layak diberi kredit atau tidak dengan menggunakan metode kualitatif deskriptif.
\end{abstract}

Keywords: Kredit kendaraan, karakter konsumen, jurnal deskriptif

\section{PENDAHULUAN}

\subsection{LatarBelakang}

Manusia memiliki banyak kebutuhan untuk menjaga keberlangsungan hidupnya. Kebutuhan manusia dapat diartikan sebagai suatu keadaan perasaan kekurangan dan kepuasan atas dasar tertentu. Manusia membutuhkan sandang, pangan, rumah, kendaraan, rasa aman dan lain-lain. Terbatasnya dana untuk memenuhi kebutuhan financial dapat menjadi suatu permasalahan bagi gaya hidup yang semakin tinggi saat ini. Keadaan seperti ini dimanfaatkan oleh pihak-pihak tertentu untuk meraup keuntungan dengan cara yang tidak sesuai dengan prosedur. Seperti yang kita ketahui calon konsumen atau peminjam kredit di daerah atau suku tertentu yang memiliki karakter keras dan tidak kooperatif.

\subsection{Rumusan Masalah}


1. Apa saja faktor-faktor penentu dalam pengambilan keputusan persetujuan pemberian fasilitas pembiayaan kredit kendaraan bermotor di pt bca finance pada konsumen daerah karakter khusus?

2. Bagaimana cara Branch Manager melakukan mitigasi atau proyeksi resiko diawal terhadap karakter calon konsumen?

1.3 Tujuan

1. Mengetahui faktor-faktor penentu pengambilan keputusan

2. Mengetahui cara menyaring karakter calon konsumen

\section{TINJAUAN PUSTAKA}

Pengambilan keputusan merupakanserangkaian proses mengidentifikasi dan memilih tindakan untuk menghadapi masalah tertentu atau mengambil keuntungan dari suatu kesempatan (James AF Stoner). Pengambilan keputusan merupakan proses inventarisir dan menilai alternatifalternatif dan menentukan pilihan di antara alternatif-alternatif tersebut (R. Wayne Mondy).

Menurut Otoritas Jasa Keuangan (OJK) perusahaan pembiayaan adalah badan usaha yang melakukan kegiatan pembiayaan untuk pengadaan barang dan/atau jasa. Kegiatan usaha perusahaan pembiayaan ada 4 yaitu:

1. Pembiayaan Investasi

2. Pembiayaan Modal Kerja

3. Pembiayaan Multiguna

4. Kegiatan usaha pembiayaan lain yang disetujui oleh OJK

Perusahaan sewa guna usaha di Indonesia lebih dikenal dengan nama leasing. Kegiatan utama perusahaan sewa guna usaha adalah bergerak di bidang pembiayaan untuk keperluan barangbarang modal yang diinginkan oleh nasabah. Pembiayaan disini maksud jika seorang nasabah membutuhkan barang-barang modal seperti peralatan kantor atau mobil dengan cara disewa atau dibeli secara kredit dapat diperoleh diperusahaan leasing. Pihak leasing dapat membiayai keinginan nasabah sesuai dengan perjanjian yang telah disepakati keduabelah pihak.

Setidaknya ada 4 pihak umumnya akan yang terlibat dalam leasing mobil. Keempat pihak tersebut yaitu :

1. Lessor artinya perusahaan leasing seperti bank atau lembaga lainnya

2. Lesse yang merupakan pengaju leasing atau nasabah yang membayar atau menyewa serta menggunakan barang.

3. Supplier yaitu pihak yang menyediakan barang untuk di-leasing-kan.

4. Asuransi yakni perusahaan yang akan menanggung resiko terhadap perjanjian lessor dengan lessee.

Perusahaan leasing dapat diselenggarakan oleh atau badan usaha yang berdiri sendiri. Keterbatasan usaha leasing adalah tidak boleh melakukan kegiatan yang dilakukan oleh bank 
seperti memberikan simpanan dan kredit dalam bentuk uang. Pengertian sewa guna usaha adalah perjanjian antara lessor (perusahaan leasing) dengan lessee (nasabah) di mana pihak lessor menyediakan barang dengan hak penggunaan oleh lesee dengan imbalan pembayaran sewa untuk jangka waktu tertentu.

Sedangkan pengertian sewa guna usaha sesuai dengan keputusan MenteriKeuangan No. 1169/ KMK.01/1991 adalah kegiatan pembiayaan dalam bentuk penyediaan barang modal, baik secara sewa guna usaha dengan hak opsi (finance lease) maupun sewa guna usaha tanpa hak opsi (operating lease) untuk digunakan oleh lessee selama jangka waktu tertentu berdasarkan pembayaran secara berkala. Selanjutnya yang dimaksud dengan finance lease kegiatan sewa guna usaha dimana lesee pada akhir masa kontrak mempunyai hak opsi untuk membeli objek sewa guna usaha berdasarkan nilai sisa yang disepakati, sebaliknya operating lease tidak mempunyai hak opsi untuk membeli objek sewa guna usaha.

Memahami Bisnis Perusahaan Pembiayaan

A. PemahamanKegiatan Usaha Perusahaan Pembiayaan

1. POJK Nomor: 28/POJK.05/2014 \& POJK Nomor: 30/POJK.05/2014

2. POJK Nomor: 29/POJK.05/2014 \& POJK Nomor: 31/POJK Nomor: 31/POJK.05/2014

B. Pemahaman Hal-hal Penting pada POJK Nomor: 28,29 \& 30/POJK.05/2014

1. POJK 28 \& 30/POJK.05/2014

2. Uang muka pembiayaan kendaraan bermotor

3. Mitigasi Resiko

4. Tingkat kesehatan keuangan perusahaan pembiayaan (TKK PP)

5. FAR (Financing to Assets Ratio)

6. Ekuitas

7. BMPP (Batas Minimum Pemberian Pembiayaan)

8. Ketentuan Sertifikasi

9. Larangan

Non Performing Loan (NPL) atau kredit bermasalah merupakan salah satu indikator kunci untuk menilai kinerja fungsi bank. Kemampuan debitur dari sisi financial untuk melunasi pokok dan bunga pinjaman tidak akan ada artinya tanpa kemauan dan itikad baik dari debitur itu sendiri.

Salah satu proses manajemen risiko setelah tahapan sesmen risiko adalah penyusunan rencana mitigasi/respons risiko. Dalam proses ini, pemilik risiko menyusun serangkaian rencana aksi penanganan guna memperkecil eksposur risiko. Dalam ISO 31000:2009, istilah mitigasi risiko disebut "risk treatment". Standar tersebut menyebutkan penanganan risiko adalah pemilihan satu atau lebih pilihan untuk memodifikasi risiko dan melaksanakan serangkaian pilihan tersebut. Dalam COSO Integrated Framework 2004, mitigasi risiko disebut "risk response“. Dalam melakukan respons risiko, pemilik risiko mengidentifikasi dan mengevaluasi respons yang 
memungkinkan yang terkait risiko. Manajemen memilih serangkaian aksi tindak lanjut selaras dengan selera dan toleransi risiko perusahaan.

Mitigasi Risiko Pembiayaan dilakukan dengan 3 cara yaitu:

1. Alihkan Risiko pembiayaan dengan asuransi kredit atau penjaminan kredit

Perusahaan asuransi / lembaga penjaminan memiliki izin dari OJK dan tidak dalam status kena sanksi / pembekuan kegiatan usaha

2. Alihkan Risiko barang yang dibiayai/ agunan dengan asuransi dibagi dua:

a. Perusahaan asuransi / lembaga penjaminan memiliki izin dari OJK dan tidak dalam status kena sanksi / pembekuan kegiatan usaha,

b. Jangka waktu asuransi minimal $=$ tenor kredit

3. Proteksi barang yang dibiayai/agunan dengan pembebanan fidusia

Kewajiban pendaftaran fidusia juga berlaku perusahaan pembiayaan yang melakukan pembiayaan penerusan (channeling) atau pembiayaan bersama (joint financing)

\section{METODE PENELITIAN}

Dalam kaitan ini Arief Furchan (1999: 22) menerangkan sebagai berikut:

Metode kualitatif ialah "proses penelitian yang menghasilkan data deskriftif, ucapan atau tulisan atau perilaku yang dapat diamati dari orang-orang itu sendiri, menurut pendapat kami pendekatan ini langsung menunjukan setting dan individu-individu dalam setting itu secara keseluruhan. Subyek penyelidikan baik berupa organisasi atau individu tidak mempersempit menjadi variable yang terpisah atau menjadi hipotesa melainkan dipandang sebagai suatu keseluruhan. Dari pendapat diatas, dapat dikatakan bahwa pendekatan kualitatif berusaha mendapatkan data deskriptif, ucapan atau tulisan dan perilaku yang dapat diamati.

Dalam penelitian ini digunakan pendekatan kualitatif dengan alasan mengacu pada beberapa alasan sebagai mana yang dikemukakan oleh. Margono (2000: 37) antara lain:

1. Untuk menanggulangi banyaknya informasi yang hilang, seperti yang dialami oleh penelitian kualitatif sehingga intisari konsep yang ada pada data dapat diungkap.

2. Untuk menaggulangi kecenderungan menggali data empiris dengan tujuan membuktikan kebenaran hipotesis akibat dari adanya hipotesis yang disusun sebelumnya berdasarkan berfikir deduktif seperti dalam pemikiran kuantitatif.

3. Untuk menanggulangi kecenderungan pembatasan variable yang sebelumnya, seperti dalam penelitian kuantitatif padahal permasalahan dan variable dalam masalah social sangat kompleks.

4. Untuk menanggulangi adanya indeks-indeks kasar seperti dalam penelitian kuantitatif yang menggunakan pengukuran enumerasi (perhitungan) empiris, padahal inti sebenarnya berada pada konsep-konsep yang timbul dari data. 
Prosedur Pengumpulan Data

Dalam penelitian kualitatif, peneliti sekaligus berfungsi sebagai instrument utama yang terjun kelapangan serta berusaha sendiri mengumpulkan data melalui wawancara dan interview.

Metode Interview

Metode ini disebut juga dengan metode wawancara, yaitu suatu metode pengumpulan data yang dilakukan melalui Tanya jawab secara langsung dengan sumber data.

Sebungan dengan hal ini Margono (2003: 165) mengemukakan bahwa: "interview merupakan alat pengumpulan informasi dengan cara mengajukan pertanyaan secara lisan, untuk dijawab secara lisan juga, cirri utama dari interview adalah kontak langsung dengan tatap muka antara pencari informasi dengan sumber informasi”.

Analisis data penelitian kualitatif pada dasarnya sudah dilakukan sejak awal kegiatan penelitian sampai akhir penelitian. Dengan cara ini diharapkan terdapat konsistensi analisis data secara keseluruhan. Karena mengingat penelitian ini bersifat deskriptif, maka digunakan analisa data filosofis atau logika yaitu analis deduktif.

Metode deduktif adalah metode berpikir dengan mengambil kesimpulan dari data-data yang bersifat umum. Dalam penelitian ini digunakan metode deduktif untuk menarik suatu kesimpulan terhadap hal-hal atau peristiwa-peristiwa dari data yang telah dikumpulkan melalui wawancara, yang bisa dikhususkan ditemukan lalu dicocokan dengan teori-teori yang ada.

\section{PEMBAHASAN}

Semakin berkembangnya dunia otomotif di Indonesia, membuat perusahaan pembiayaan menjadi salah satu alternatif untuk menunjang kebutuhan konsumen untuk memiliki kendaraan bermotor. Salah satu perusahaan yang cukup menunjukkan eksistensi dalam dunia leasing adalah BCA Finance. BCA finance berdiri mulai dari tahun 1981 dengan nama PT Central Sari Metropolitan Leasing Corporation. Pada awal berdirinya pemegang saham Perusahaan adalah PT Bank Central Asia dan Japan Leasing Corporation. Saat itu Perusahaan masih memfokuskan usaha pada pembiayaan komersial, seperti pembiayaan mesin-mesin produksi, alat berat dan transportasi.

Selanjutnya pada tahun 2001 PT Central Sari Metropolitan Leasing berubah nama menjadi PT Central Sari Finance (CSF), diikuti dengan perubahan kepemilikan saham, dimana PT Bank Central Asia, Tbk (BCA) menjadi pemegang saham mayoritas, serta perubahan fokus usaha menjadi pembiayaan kendaraan bermotor, khususnya roda empat atau lebih. Terakhir, Sesuai dengan Surat Keputusan Menteri Hukum dan Hak Asasi Manusia Republik Indonesia No.C08091 HT.01.04.TH.2005, maka per tanggal 28 Maret 2005 PT Central Sari Finance telah berubah nama menjadi PT BCA Finance. 
Seiring dengan perubahan nama tersebut, pertumbuhan BCA Finance pun semakin melesat tajam. Hal ini tercermin dari terus meningkatnya jumlah pelepasan pembiayaan baru dan total asset kelolaan secara signifikan. Prestasi ini tidak terlepas dari dukungan penuh yang diberikan oleh Perusahaan induk kami yaitu PT Bank Central Asia, Tbk.

Dalam bidang pembiayaan, sampai dengan saat ini Perusahaan masih tetap fokus di sektor pembiayaan mobil. Dari waktu ke waktu BCA Finance berupaya secara terus menerus untuk meningkatkan market share Perusahaan, baik dengan penerapan strategi yang tepat, melakukan ekspansi pembukaan cabang-cabang baru maupun dengan senantiasa memberikan pelayanan terbaik kepada para customernya. Perusahaan telah memiliki jaringan usaha yang relatif luas yang tersebar di berbagai kota besar di seluruh Indonesia.

Seiring dengan berjalannya waktu masalah yang dihadapi semakin kompleks. Terjadi berbagai upaya penggelapan yang sengaja dilakukan oleh konsumen untuk mendapatkan kendaraan yang mereka inginkan. Berdsarkan informasi yang diperoleh dari admin collection terdapat masalah yaitu terjadinya wanprestasi oleh beberapa nasabah BCA Finance. Nasabah yang pembayarannya terlambat dari tanggal jatuh tempo akan ditangani oleh pihak collection. Dimulai dari pihak admin collection melakukan konfirmasi kepada konsumen melalui telepon untuk mengkonfirmasi supaya konsumen segera melakukan pembayaran angsuran dan konfirmasi denda yang ditanggung akibat keterlambatan pembayaran angsuran. Jika nsabah masih tidak menghiraukan konfirmasi yang dilakukan admin collection melalui telepon maka pihak collection akan melakukan penagihan secara tertulis yang dikirim ke alamat konsumen. Apabila konsuemn tetap tidak kooperatif maka akan dilakukan penagihan secara langsung ke rumah konsumen oleh pihak ketiga rekanan BCA Finance. Prosedural terakhir pihak admin collection yang dilakukan adalah menyita kendaraan konsumen melalui pihak ketiga. Sehubungan dengan semakin banyaknya konsumen atau nasabah yang menunggak maka pihak manajemen BCA Finance melakukan evaluasi pengambilan keputusan untuk mengklasifikasikan daerah- daerah yang sering menunggak pembayaran angsuran serta menambah kriteria khusus untuk daerahdaerah tersebut. Contoh, calon konsumen berdomisili di daerah seperti Madura, Kediri, Lamongan dan Gresik wajib melakukan verifikasi data konsumen, survey alamat konsumen yang valid, serta mendapatkan rekomendasi dari pihak collection, Branch manager dan Regional Manager Marketing serta Admin Collection Head.

Faktor-faktor yang menentukan pengambilan keputusan dari pihak Pejabat terkait adalah:

1. Wilayah atau domisili konsumen.

Hal ini meliputi bukti rumah seperti bukti bayar PBB, rekening listrik rekening PDAM terbaru, validasi data KTP dan KK calon konsumen.

2. Kemampuan membayar.

Hal ini dipertimbangkan dari pekerjaan konsumen, bukti penghasilan dan jumlah tanggungan calon konsumen. 
3. Riwayat perbankan.

Hal ini bisa dilihat melalui sistem Bank Indonesia Checking dan mutasi rekening BCA calon konsumen.

4. Survey

Hal ini dilakukan untuk mengetahui kebenaran data yang sudah diberikan oleh calon konumen. Seperti sesuai atau tidaknya alamat domisili atau alamat tinggal sekanag si calon konsumen dengan KTP dan KK yang sudah diberikan sebagai syarat pengajuan kredit.

Terkait hal tersebut diatas pengambilan keputusan oleh seorang Branch Manager dalam melakukan mitigasi atau proyeksi resiko diawal terhadap karakter calon konsumen adalah sebagai berikut:

1. Melakukan pengecekan validitas dokumen identitas dengan cara menmbandingkan dengan database dispenduk capil,

2. Melakukan pengecekan terhadap kesesuaian kondisi ekonomi terhadap jenis mobil yang diambil. Misalnya: unit fortuner pasti calon konsumen memiliki status ekonomi tinggi,

3. Melakukan pengecekan pekerjaan dan jumlah penghasilan terhadap mutasi tabungan, dan

4. Melakukan pengecekan peruntukan mobil yang akan dibeli

\section{KESIMPULAN}

Dari berbagai uraian diatas dapat ditarik kesimpulan. Dari hasil data internal audit pemetakan kota atau daerah karakter khusus seperti Madura, Kediri, Lamongan, Gresik merupakan penyumbang NPL (Non Performing Loan atau kredit bermasalah) tertinggi. Bahwa konsumen di daerah karakter khusus tetap diberikan fasilitas pembiayaan kredit asal diwajibkan untuk melakukan dobel survey disertai dengan pimpinan cabang dan DP (Down Payment) untuk pengajuan kredit minimal 45\% dari OTR. Dan untuk calon konsumen yang akan mengajukan kredit khusus kendaraan pajero dan fortuner diwajibkan untuk dilakukan survey oleh credit marketing officer ataupun dilakukan survey dari outsourching (survey eksternal yang sudah rekanan contohnya mahadaya, ponny express survey). Hal tersebut menjadi pertimbangan pimpinan cabang agar mengetahui secara langsung kondisi kelayakan konsumen yang akan diberikan fasilitas kredit oleh PT BCA Finance. 


\section{DAFTAR PUSTAKA}

http://lontar.ui.ac.id/file?file=digital/127600-T+26379-Analisis+pengukuran-

Tinjauan+literatur.pdf

Yogi Iskandar; 2016; Peran Leasing dalamPengembangan Perusahaan BaikdalamBidangJasaMaupundalamBidangProduksi

(http://gudangilmu79.blogspot.co.id/2016/01/peran-leasing-dalam-pengembangan.html diakses tanggal 27 Desember 2017)

Maria Marlyn Monulandi . 2016. PERSEPSI NASABAH TERHADAP PENERAPAN PRINSIP 5C DALAM PENYALURAN KREDIT USAHA RAKYAT (KUR) OLEH PT. BANK RAKYAT INDONESIA (PERSERO), TBK UNIT TOMBATU, MINAHASA TENGGARA. ejournal.unsrat.ac.id

Anzizhan, Syafaruddin. Sistem pengambilan keputusan pendidikan.Ebook.

Alimudin, A., \& Yoga, H. (2015). STRATEGI MENINGKATKAN LOYALITAS PELANGGAN PADA USAHA KECIL PRODUK MAKANAN RINGAN DI SURABAYA. Sustainable Competitive Advantage (SCA), 5(1).

http://www.bcafinance.co.id/home/index.html

Didi Wahyu Sudirman. 2003. Pengambilan Keputusan sebagai Langkah Strategis Tugas Manajer. journal.uny.ac.id, 3(2): 93-101.

ItaLizawati dan A Kistyanto. 2014. Pengaruh Gaya Kepemimpinan Transformasional

Kreitner, Robert dan Kinicki, Angelo. 2005. Perilaku Organisasi. Jakarta: Salameba Empat Terhadap Efektivitas Organisasi Melalui Pengambilan Keputusan.JurnalMahasiswa Teknologi, 1 (6): 1606-1618.

Ayu Trieesnaning Rahmawati, Muhammad Saifi, Raden Rustam Hidayat.2016. Analisis Pemberian Kredit Dalam Langah Meminimailisir Kredit Bermasalah. Administrasibisnis.studentjurnal.ub.ac.id 